\title{
RESPONS PERMINTAAN PANGAN TERHADAP PERTAMBAHAN PENDUDUK DI SUMATERA BARAT
}

\author{
RESPONSE OF FOOD DEMAND TO POPULATION \\ INCREASE IN WEST SUMATERA
}

\author{
Rusda Khairati ${ }^{1}$ dan Rahmat Syahni ${ }^{2}$ \\ 1,2 Universitas Andalas Padang \\ Kampus Limau Manis, Pauh, Padang 25163 \\ Telp. (0751) 71581 \\ Email: rusdakhairati@yahoo.co.id
}

Naskah disetujui : 10-12-2016

\begin{abstract}
The objective of this research is to estimate the demand response ofmain food (rice, meat, egg, and milk) to population increasein West Sumatera.To achieve this objective, we use multiple regression analysis using secondary data of West Sumatera from 2002 to 2013. In this case we use the product price, total population, and per kapita income asindependent variabels; and food demand as dependent variabel. The result shows that only total population significantly influence the demandon rice, meat, eggs, and milk, with coefficient of response $8 \%$ for rice; $2.95 \%$ for meat; $4.37 \%$ for eggs, and $14.03 \%$ for milk.These numbers shows that the demand on food is very elastic to the increase of total population. It means that the $1 \%$ increase on total population, would increase about $8 \%$ demand on rice; about $2.95 \%$ demand on meat; $4.37 \%$ demand on eggs, and $14.03 \%$ demand on milk.
\end{abstract}

Keywords: Food demand, response of food demand, population increase

Penelitian ini bertujuan untuk menduga seberapa besar respons permintaan terhadap pangan utama (padi-padian, daging, telur dan susu)terhadap pertambahan jumlah penduduk di Sumatera Barat. Untuk mencapai tujuan penelitian ini digunakan pendekatan kuantitatif dengan analisis regresi berganda dan perhitungan ukuran respons permintaandengan menggunakan data sekunder dari tahun 2002 sampai dengan 2013. Variabel bebas yang dianggap berpengaruh adalah harga produk, jumlah penduduk dan pendapatan per kapita, sedangkan variabel terikat adalah permintaan terhadap pangan.Dari hasil analisis ternyata hanya variabel jumlah penduduk yang berpengaruh signifikan terhadap permintaan pangan padi-padian, daging, telur dan susu, dengan angka respons permintaan berturut-turut $8 \%$ untuk padi-padian; $2,95 \%$ untuk daging; $4,37 \%$ untuk telur dan $14,03 \%$ untuk susu. Angka ini menunjukkan bahwa permintaan pangan terhadap pertambahan penduduk sangat elastis, artinya jika penduduk bertambah $1 \%$, maka permintaan meningkat $8 \%$ untuk pangan padi-padian; $2,95 \%$ untuk daging; $4,37 \%$ untuk telur; dan $14,03 \%$ untuk susu.

Kata Kunci: Permintaan pangan, respons permintaan pangan, pertambahan penduduk

\section{PENDAHULUAN}

Pangan merupakan kebutuhan

dasar bagi manusia untuk dapat bertahan hidup. Ketersediaan pangan pada suatu wilayah sangat penting peranannya untuk memenuhi permintaan penduduk bagi pertumbuhan, pemeliharaan, dan peningkatan derajat kesehatan serta peningkatan kecerdasan masyarakat. Oleh karena itu ketersediaan pangan merupakan prioritas utama yang harus dipenuhi. Ketahanan pangan juga merupakan salah satu faktor utama dalam pembangunan nasional yaitu untuk membentuk manusia Indonesia yang berkualitas, mandiri dan sejahtera, 
yang diwujudkan melalui ketersediaan pangan yang cukup, aman, bermutu, bergizi, beragam, tersebar merata, dan terjangkau oleh masyarakat.

Terpenuhinya ketersediaan pangan adalah hak asasi masyarakat dan sekaligus kewajiban pemerintah. Melalui UU No 32 Tahun 2004 (sebagaimana telah dirubah menjadi UU No 23 Tahun 2014) Tentang Pemerintahan Daerah, dan Peraturan Pemerintah No. 38 Tahun 2007 Tentang Pembagian Urusan Pemerintah antara Pemerintah Pusat, Pemerintah Provinsi dan Pemerintah Kabupaten /Kota dijelaskan bahwa urusan ketahanan pangan merupakan urusan wajib pemerintah berkaitan dengan pelayanan dasar dalam pemenuhan kebutuhan hidup minimal. Sedangkan dalam penyelenggaraan ketahanan pangan, peran pemerintah provinsi dan kabupaten/kota adalah melaksanakan dan bertanggung jawab terhadap penyelenggaraan ketahanan pangan di wilayah masing-masing dan mendorong keikutsertaan masyarakat dalam penyelenggaraan ketahanan pangan.

Laju peningkatan kebutuhan pangan lebih cepat dibandingkan dengan laju peningkatan kemampuan produksinya (www.foodsecurityatlas.org). Hal ini diantaranya disebabkan karena di beberapa wilayah di Indonesia semakin terbatasnya kapasitas produksi pangan. Dijelaskan bahwa ada beberapa penyebab semakin terbatasnya kapasitas produksi pangan nasional: 1) berlanjutnya konversi lahan pertanian ke penggunaan non pertanian; 2) menurunnya kualitas dan kesuburan lahan akibat kerusakan lingkungan; 3) semakin terbatas dan tidak pastinya ketersediaan air untuk produksi pangan akibat kerusakan hutan; 4) pemanfaatan sumberdaya air dengan sektor industri dan pemukiman.

Sementara itu laju pertumbuhan penduduk yang tinggi di Indonesia merupakan tantangan yang perlu dihadapi. Laju pertumbuhan penduduk yang tinggi, akan meningkatkan persaingan antara penyediaan kebutuhan lahan untuk produksi pangan dan untuk kebutuhan lainnya. Sejalan dengan pertumbuhan penduduk, kebutuhan penduduk akan pangan juga semakin meningkat, karena besarnya jumlah penduduk terkait langsung dengan penyediaan pangan. Di sisi lain luas lahan pertanian semakin sedikit karena kebutuhan lahan untuk nonpertanian juga terus meningkat seiring dengan meningkatnya jumlah penduduk. 
Dari tahun ke tahun konsumsi pangan beras sebagai pangan utama penduduk Indonesia selalu mengalami peningkatan. Dengan prediksi jumlah penduduk Indonesia 350 juta tahun 2030, maka kebutuhan beras penduduk meningkat mencapai angka 90-100 juta ton per tahun (www.bps.co.id, 2010). Dari hasil penelitian Khairati (2014) terlihat bahwa di beberapa kabupaten dan kota di Sumatera Barat telah terjadi penurunan pertumbuhan luas tanam padi, yaitu di Kabupaten Mentawai, Pesisir Selatan, Kota Padang, Kota Solok dan kota Sawah Lunto, berturut turut -3,69; -0,58;-0,58; 4,25 dan $-1,68$ persen. Juga ditemukan bahwa di sebagian besar kabupaten dan kota di Sumatera Barat laju pertumbuhan penduduknya lebih tinggi dari laju pertumbuhan luas tanam padi. Di Kabupaten Mentawai, Pesisir Selatan, Sawahlunto Sijunjung, Padang Pariaman, Agam, dan Pasaman Barat pertumbuhan penduduknya lebih besar dari pertumbuhan luas tanam padi.

Di Sumatera Barat juga terjadi ketidak seimbangan pertumbuhan produksi pangan dan pertumbuhan penduduk. Hal ini terjadi tidak hanya untuk padi, tapi juga termasuk pangan penting lain, seperti daging dan telur (Khairati, 2012). Di Kabupaten Mentawai dan Kabupaten Sijunjung, Kota Solok dan Kota Sawahlunto, pertumbuhan produksi padinya lebih kecil dari pertumbuhan penduduk. Sedangkan Kabupaten Mentawai, Kabupaten Sijunjung, Kabupaten Padang Pariaman, Kabupaten Lima Puluh Kota, Kota Padang, Kota Solok dan Kota Payakumbuh mengalami pertumbuhan produksi daging yang lebih kecil dari pertumbuhan penduduknya.

Terjadinya ketidak seimbangan pertumbuhan penduduk dengan pertumbuhan produksi pangan di hampir semua kabupaten dan kota di Sumatera Barat dapat menyebabkan kekurangan pasokan pangan, atau terjadinya kelebihan permintaan dibandingkan penawaran pangan, sehingga mendorong peningkatkan harga, dan akhirnya dapat menurunkan daya beli masyarakat di kabupaten dan kota yang bersangkutan, padahal pemenuhan konsumsi pangan melalui penyediaan dalam negeri adalah lebih penting.

Jika kebutuhan pangan untuk penduduk ini tidak dapat dipenuhi maka akan mengakibatkan Indonesia menjadi negara pengimpor pangan. Untuk mengantisipasi ketersediaan pangan bagi penduduk, dengan bertambahnya jumlah penduduk dan meningkatnya 
penggunaan lahan untuk kebutuhan pertanian dan non pertanian, maka penulis merasa perlu melakukan penelitian untuk melihat seberapa besar respons perubahan permintaan pangan penduduk terhadap pertambahan jumlah penduduk setiap tahun.

Berdasarkan latar belakang di atas, masalah dalam tulisan ini difokuskan pada seberapa besar persen respons pertambahan permintaaan pangan padipadian, daging, telur dan susu di Sumatera Barat dengan bertambahnya jumlah penduduk. Tulisan ini bertujuan untuk melihat besarnya respons permintaan penduduk terhadap pangan, yaitu padi-padian, daging, telur dan susu di Sumatera Barat teradap pertambahan jumlah penduduk.

Secara teoritis, permintaan adalah keinginan yang disertai dengan kemampuan serta kesediaan untuk membeli (Rosyidi, 1998). Permintaan penduduk terhadap suatu komoditi atau barang akan dipengaruhi oleh beberapa faktor, yaitu: 1) Harga barang yang bersangkutan, 2) Harga barang subsitusi, 3) Harga barang komplemen, 4) Selera penduduk, 5) Pendapatan rumah tangga, 6) Jumlah penduduk, dan 7) Ramalan dimasa yang akan datang (Sukirno, 2002).
Respons permintaan adalah suatu ukuran tingkat respons jumlah yang diminta dari suatu produk tertentu terhadap perubahan salah satu variabel bebas yang mempengaruhi permintaan produk tersebut, yang dikenal dengan elastisitas (Pass, Bryan dan Leslie, 1998). Sedangkan menurut Rahardja dan Mandala (2014), elastisitas permintaan terhadap suatu barang mengukur perubahan relatif dalam jumlah unit barang yang dibeli sebagai akibat perubahan salah satu faktor yang mempengaruhi permintaan (ceteris paribus). Umumnya respons dikaitkan dengan harga dan pendapatan yang diukur dengan elastisitas. Menurut Varian (1990), elastisitas permintaan mengukur derajat kepekaan jumlah barang yang diminta terhadap perubahan harga.

Rosyidi (1998) mendefinisikan elastisitas sebagai suatu ukuran kepekaan yang menyatakan seberapa jauh jumlah sesuatu barang yang diminta berubah karena adanya perubahan harga, jika semua hal yang dapat menggeser kurva permintaan dianggap tetap. Hal-hal yang mempengaruhi elastisitas adalah: 1) Ada atau tidaknya barang pengganti, 2) Luas atau sempitnya penggunaan 
barang tersebut, 3) Pentingnya barang yang bersangkutan bagi kehidupan, dan 4) Sifat tahan lamanya sesuatu barang.

Dari hasil penelitian Riyanto, Ridwansyah, dan Umiyati (2013) didapatkan bahwa perubahan jumlah penduduk lebih elastis terhadap permintaan beras.Dijelaskan juga bahwa variabel yang paling berpengaruh dalam peningkatan permintaan beras adalah jumlah penduduk. Permintaan beras akan meningkat sejalan dengan semakin bertambahnya jumlah penduduk.

Jumlah penduduk yang besar dan laju pertumbuhan penduduk yang tinggi menuntut ketersediaan kebutuhan penduduk untuk pangan dan non pangan yang tinggi pula. Laju pertumbuhan penduduk Indonesia saat ini sebesar 1,49\%. Dari hasil sensus penduduk tahun 2010, jumlah penduduk Indonesia mencapai 237,56 juta jiwa, yang menempatkan Indonesia sebagai negara dengan jumlah penduduk nomor empat terbesar di dunia setelah Cina, India, dan Amerika Serikat. Dari hasil proyeksi penduduk terlihat bahwa jumlah penduduk Sumatera Barat selama sepuluh tahun ke depan juga akan terus mengalami peningkatan, yaitu dari 4.865.331 pada tahun 2010 mencapai
5.498.751 jiwa pada tahun 2020

(BKKBN Sumatera Barat, 2015).

Menurut Badan Ketahanan Pangan Sumatera Barat (2015), produksi beras Sumatera Barat terus mengalami kanaikan, rata-rata 3-5\% per tahun, namun lonjakan pertumbuhan penduduk juga terjadi, sehingga kebutuhan pangan juga meningkat. Selain jumlah penduduk yang selalu naik, lahan persawahan juga mengalami penurunan karena beralih menjadi pemukiman penduduk dan bangunan lainnya.Menurut catatan Dinas Pertanian Sumatera Barat, luas lahan sawah di Sumatera Barat terus berkurang.Dalam 10 tahun terakhir telah terjadi pengurangan lahan sawah sebanyak 2 ribu ha karena pengembangan pemukiman (www.puailiggoubat.com).

Berdasarkan angka Statistik Konsumsi Pangan (Pusat Data dan Sistem Informasi Pertanian, 2012), konsumsi beras penduduk di Sumatera Barat per kapita dari tahun 2007 sampai dengan tahun 2011 berturut- turut adalah 117,78 $\mathrm{kg} ; 115,84 \mathrm{~kg} ; 115,53 \mathrm{~kg} ; 109,56 \mathrm{~kg}$; dan $112,65 \mathrm{~kg}$, mengalami penurunan sampai dengan tahun 2010 tetapi kembali mengalami kenaikan pada tahun 2011.

Di sisi lain, konsumsi daging sapi Sumatera Barat selalu mengalami peningkatan dari tahun ke tahun. Secara 
berturut turut konsumsi daging sapi penduduk Sumatera Barat dari tahun 2011 sampai tahun 2013, adalah : 35.546 ton; 36.636 ton dan 38141 ton, dengan konsumsi rata-rata per kapita per tahun sebesar $7.320 \mathrm{~kg}$; $776 \mathrm{~kg}$; dan $7707 \mathrm{~kg}$. Daging sapi merupakan salah satu jenis pangan yang perlu mendapat perhatian dalam hal penyediaannya, karena dalam dasawarsa terakhir terdapat kecenderungan peningkatan nilai impor, karena produksi dalam negri belum dapat memenuhi permintaan penduduk.

Menurut Direktorat Jenderal Peternakan (2015), produksi daging Sumatera Barat dari tahun 2011 sampai 2015 (angka sementara) berturut-turut sebesar 20.287 ton (2011); 22.638 ton (2012); 23.099 ton (2013); 24.943 ton (2014), dan 25.981 (2015). Konsumsi daging di Sumatera Barat dari tahun ke tahun mengalami peningkatan, dengan laju pertumbuhan sebesar 2,45\% dari tahun 2006-2013 (Data diolah dari Statistik Dalam Angka Sumatera Barat, dari tahun 2006 sampai tahun 2013).

Konsumsi telur di Sumatera Barat juga mengalami peningkatan setiap tahun. Tahun 2011 ada 41.917 ton telur dikonsumsi oleh penduduk, tahun 2012 meningkat menjadi 42.612 ton dan pada tahun 2013 meningkat lagi menjadi
45.424 ton, dengan konsumsi per kapita per tahun pada tahun 2013 sebesar 9.178 kg (Sumatera Barat Dalam Angka, 2013). Jika dibandingkan antara pertumbuhan konsumsi telur penduduk dengan produksi telur di Sumatera Barat antara tahun 2006-2013, terlihat bahwa pertumbuhan konsumsi lebih besar dari pertumbuhan produksi.

Konsumsi susu tahun 2011 sampai 2013 mengalami penurunan. Berturut turut tiga tahun terakhir konsumsi Susu penduduk Sumatera Barat adalah 35.865 ton tahun 2011; 37.657 ton tahun 2012 dan 32.282 pada tahun 2013. Dibandingkan dengan konsumsi tahun 2012. Namun dari tahun 2006 sampai 2013 terjadi kecenderungan peningkatan konsumsi, dimana konsumsi susu penduduk Sumatera Baratsebagian besar diperoleh dari susu impor, rata-rata 93,6\% tiap tahun adalah susu impor. Konsumsi susu penduduk Sumatera Barat meningkat sangat tinggi, yaitu tumbuh sebesar $33,57 \%$. Sementara kecenderungan produksi susu terjadi penurunan, yaitu sebesar $-1,48 \%$.

Dari data-data statistik di atas terlihat bahwa terjadi kecenderungan peningkatan konsumsi penduduk terhadap beras, daging, telur dan susu. Namun seberapa besar respon 
pertambahan permintaan penduduk terhadap pangan tersebut dengan meningkatnya jumlah penduduk belum diketahui. Jika bertambah penduduk satu persen, berapa persen bertambahnya permintaan terhadap komoditi pangan beras (padi-padian), daging, susu dan telur belum diketahui, karena memang belum ada penelitian sebelumnya tentang hal tersebut.

Penelitian Riyanto, dkk (2013) di Provinsi Jambi hanya melihat elastisitas permintaan beras, yang menunjukkan bahwa permintaan beraselastis terhadap perubahan jumlah penduduk. Dijelaskan juga bahwa variabel yang paling berpengaruh dalam peningkatan permintaan beras adalah jumlah penduduk. Permintaan beras akan meningkat sejalan dengan semakin bertambahnya jumlah penduduk. Di Sumatera Barat respons perubahan jumlah penduduk terhadap permintaan pangan beras atau padipadian, daging, susu dan telur belum pernah diteliti sebelumnya. Oleh karena itu penulis merasa perlu melihat bagaimana respons perubahan jumlah penduduk, harga, dan pendapatan penduduk terhadap permintaan beras, daging, susu dan telur.

Seberapa besar respons permintaan pangan penduduk terhadap pertambahan jumlah penduduk, bisa diukur dengan koefisien elastisitas.Secara teoritis, elastisitas permintaan adalah suatu ukuran tingkat respon jumlah yang diminta dari suatu produk tertentu terhadap perubahan salah satu variabel bebas yang mempengaruhi permintaan produk tersebut (Pass, Bryan dan Leslie, 1998). Umumnya Elastisitas dikaitkan dengan harga dan pendapatan sebagai variabel bebas.Tetapi karena jumlah penduduk, juga merupakan salah satu variabel bebas yang berpengaruh terhadap permintaan pangan, maka mengukur respons permintaan pangan terhadap pertambahan penduduk berarti mengukur elastisitas.

Konnsumsi pangan utama penduduk Indonesia dan khususnya Sumatera Barat diantaranya adalah padipadian (beras), daging, telur dan susu. Pada tulisan ini akan dilihat seberapa besar respons pertambahan permintaan penduduk terhadap pangan padi-padian yang mewakili permintaan beras, pangan daging, telur, dan susu terhadap perubahan harga pangan bersangkutan, pendapatan penduduk dan jumlah penduduk.

\section{METODOLOGI}

Berdasarkan studi pustaka dan kerangka pemikiran diatas, kajian ini menggunakan pendekatan kuantitatif dengan analisis regresi berganda untuk 
penghitungan respons permintaan. Penelitian ini hanya melihat bagaimana respons permintaan pangan padi-padian, daging, telur dan susu terhadap perubahan harga, perubahan pendapatan, dan jumlah penduduk dari tahun ke tahun,dengan asumsi faktor-faktor lain dianggap tetap dan tidak berpengaruh.

Respons permintaan pangan penduduk di Sumatera Barat dianalisis dari data sekunder, Sumatera Barat Dalam Angka (BPS) dalam bentuk data deret waktu, dari tahun 2002 sampai dengan tahun 2013. Data ini dipilih berdasarkan kelengkapan data yang tersedia. Secara umum respons permintaan menggambarkan derajat kepekaan atau respons dari jumlah barang yang diminta, akibat perubahan faktor yang mempengaruhi.

Respons permintaan komoditi pangan yang diukur adalah beras yang termasuk dalam kelompok padi padian, daging, telur dan susu sebagai pangan utama penduduk, sedangkan faktor yang mempengaruhi permintaan pangan padipadian, daging, telur dan susu adalah harga produk pangan yang bersangkutan, pendapatan penduduk dan jumlah penduduk. Karena keterbatasan ketersediaan data konsumsi beras, maka khusus untuk konsumsi beras data yang tersedia dan dipakai adalah pengeluaran penduduk untuk padi padian, maka pengeluaran penduduk untuk padi padian dianggap sebagai data pengeluaran atau konsumsi untuk beras. Sedangkan untuk pangan jenis daging, telur dan susu, data konsumsi tersedia setiap tahun.

Secara teoritis elastisitas permintaan adalah suatu ukuran tingkat respon jumlah yang diminta dari suatu produk tertentu terhadap perubahan salah satu variabel bebas yang mempengaruhi permintaan produk tersebut (Pass, Bryan dan Leslie, 1998), maka untuk mengukur respons permintaan suatu komoditi terhadap perubahan variabel bebas yang mempengaruhi permintaan digunakan rumus elastisitas, yaitu: $\% \Delta \mathrm{Y} / \% \Delta \mathrm{X}$.

$$
\text { Rumus elastisitas tersebut }
$$
menunjukkan rasio persentase perubahan permintaan $\left(\mathrm{Y}_{\mathrm{i}}\right)$ terhadap persentse perubahan variabel bebas yang mempengaruhi permintaan $\left(\mathrm{X}_{\mathrm{j}}\right)$.Untuk penelitian ini $Y_{i}$ adalah permintaan untuk pangan beras (padi-padian, daging, telur, dan susu) dan $X_{j}$ adalah harga padipadian, pendapatan penduduk, dan jumlah penduduk sebagai variabel bebas yang mempengaruhi permintaan.

Pengeluaran untuk padi-padian sebagai data pengeluaran untuk beras 
merupakan variabel terikat yang diukur dengan triliun rupiah per tahun $\left(\mathrm{Y}_{1}\right)$. Konsumsi daging sebagai variabel terikat diukur dalam ton per tahun $\left(\mathrm{Y}_{2}\right)$, konsumsi telur sebagai variabel terikat diukur dalam ton per tahun $\left(\mathrm{Y}_{3}\right)$, dan konsumsi susu sebagai variabel terikat diukur dalam ton per tahun $\left(\mathrm{Y}_{4}\right)$. Harga beras, harga daging, harga telur, dan harga susu, diukur dalam rupiah per $\mathrm{kg}$; pendapatan penduduk diukur dalam rupiah per kapita, sedangkan jumlahpenduduk, diukur dalam jiwa per tahun.

Dengan analisis regresi linier bergandaantara pengeluaran penduduk per tahun untuk pangan padi-padian, konsumsi daging, konsumsi telur dan konsumsi susu $\left(\mathrm{Y}_{\mathrm{i}}\right)$, dengan harga, pendapatan penduduk dan jumlah penduduk,didapatkan besarnya koefisien regresi $\left(\beta_{\mathrm{j}}\right)$ hubungan antara pengeluaran penduduk terhadap padi-padian, daging, telur dan susu dengan harga, pendapatan penduduk dan jumlah penduduk, yang mengukur besarnya pertambahan permintaan pangan yang bersangkutan karena perubahan harga pangan, pendapatan penduduk dan pertambahan penduduk. Model regresi linier berganda untuk analisis inidapat dituliskan sebagai berikut :
$Y=\beta_{0}+\beta_{1} X_{1}+\beta_{2} X_{2}+\beta_{3} X_{3}+\epsilon$

dimana $\mathrm{Y}$ adalah permintaan pangan, $X_{1}$ harga pangan, $X_{2}$ pendapatan penduduk, dan $\mathrm{X}_{3}$ jumlah penduduk.

Respons permintaan merupakan rasio persentase pengeluaran untuk pangan (padi-padian, daging, telur dan susu) terhadap persentase pertambahan harga produk, pendapatan penduduk dan jumlah penduduk. Untuk memperoleh angka tersebut, besarnya koefisien regresi hubungan antara permintaan pangan (padi-padian, daging, telur dan susu) dengan harga pangan, pendapatan dan jumlah pendudukdikalikan dengan rasio ratarata harga pangan, pendapatan penduduk dan jumlah penduduk dengan rata-rata permintaan penduduk untuk masing-masing komoditi pangan tersebut.

Respons permintaan terhadap variabel bebas dapat dinyatakan dalam elastisitas busur (Rosyidi, 1998) sebagai berikut:

$$
\mathrm{E}=\frac{\% \Delta \mathrm{Q}}{\% \Delta \mathrm{P}}=\frac{\Delta \mathrm{Q} / \sum \mathrm{Q}}{\Delta \mathrm{P} / \sum \mathrm{P}} .
$$

Dalam penelitian ini respons permintaan pangan ke-i (padi-padian, daging, teluir, dansusu) terhadap variabel bebas ke-j (harga komoditi pangan, jumlah 
penduduk, dan pendapatan penduduk) dinyatakan sebagai:

$E=\frac{\% \Delta Y i}{\% \Delta X j}=\frac{\partial Y i / \sum Y i}{\partial X_{j} / \sum X j}=\frac{\partial Y i / \overline{Y i}}{\partial X j / \overline{X j}}=\frac{\partial Y i}{\partial X j} \cdot \frac{\bar{X} j}{\bar{Y} i}$

Dalam hal ini $\bar{Y} i$ adalah rata-rata permintaan komoditi ke-i dan $\overline{\mathrm{X}} \mathrm{j}$ adalah rata-rata variabel bebas ke-j. Sedangkan $\partial \mathrm{Yi} / \partial \mathrm{Xj}$ adalah koefisien regresi permintaan komoditi ke-i dengan variabel bebas ke-j.

Secara lebih khusus $\overline{\mathrm{X}} 1$ adalah rata-rata harga pangan, $\bar{X} 2$ adalah rata-rata pendapatan penduduk, dan $\overline{\mathrm{X}} 3$ adalah rata-rata jumlah penduduk.Sedangkan $\overline{\mathrm{Y}}_{1}$ adalah rata-rata pengeluaran penduduk per tahun terhadap padi-padian tahun 2002-2013, $\overline{\mathrm{Y}}_{2}$ adalah rata-rata konsumsi penduduk per tahun terhadap dagingtahun 2002-2013, $\overline{\mathrm{Y}}_{3}$ adalah ratarata konsumsi penduduk per tahun terhadap telurtahun 2002-2013, dan $\overline{\mathrm{Y}}_{4}$ adalah rata-rata konsumsi penduduk per tahun terhadap susutahun 2002-2013. Koefisien regresi $\beta_{\mathrm{i}}$ diperoleh dari regresi linier berganda antara permintaan padipadian, daging, telur dan susu terhadap harga pangan, pendapatan jumlah penduduk.

\section{HASIL DAN PEMBAHASAN}

Dari hasil regresi hubungan antara permintaan pangan (padi-padian, daging, telur dan susu) dengan variabel yang mempengaruhi, yaitu harga pangan, jumlah penduduk dan pendapatan per kapita ditemukan adanya multi kolinieritas antara variabel bebas harga pangan, jumlah penduduk dan pendapatan, yang terindikasi dari tingginya angka VIF (Variance Inflection Factor), yaitu jauh lebih besar dari 10 . Oleh karena itu dilakukan analisis regresi ulang dengan mengeluarkan variabel pendapatan sebagai variabel yang berpengaruh. Hasil regresi hubungan antara permintaan pangan dengan dua variabel bebas jumlah penduduk dan harga ternyata masih menunjukkan adanya multi kolinieritas antara dua variabel bebas jumlah penduduk dan harga pangan.Akhirnya variabel harga juga dikeluarkan dari model, sehingga hanya satu variabel bebas jumlah penduduk yang berpengaruh terhadap permintaan pangan. Sementara hasil Uji Durbin-Watson tidak menunjukkan adanya autokorelasi yang berarti dalam persamaan regresi yang digunakan.

Dari hasil pengolahan data terlihat bahwa perubahan variabel jumlah penduduk dapat menjelaskan terjadinya 
perubahan permintaan pangan beras (padi-padian); daging, telur dan susu. Hal ini ditunjukkan oleh angka koefisien determinasi $\left(\mathrm{R}^{2}\right)$ yang relatif tinggi, yaitu 0,85 untuk padi-padian; 0,88 untuk daging; 0,92 untuk telur; dan 0,81 untuk susu (Tabel 1). Relatif tingginya nilai Koefisien Determinasi $\left(\mathrm{R}^{2}\right)$ yang diperoleh menunjukkan bahwa model yang digunakan dengan hanya satu variabel bebas jumlah penduduk relatif baik, karena perubahan jumlah penduduk bisa menjelaskan perubahan permintaan pangan, sebesar $85 \%$ untuk padi-padian; $88 \%$ untuk daging; $92 \%$ untuk telur dan $81 \%$ untuk susu. Dengan kata lain, variabel lain selain jumlah penduduk (harga pangan yang bersangkutan, harga pangan lain yang terkait, pendapatan, selera, dan kondisi dimasa yang akan datang) hanya bisa menjelaskan perubahan permintaan $15 \%$ untuk pangan padi-padian; $12 \%$ untuk daging; $8 \%$ untuk telur dan $19 \%$ untuk susu.

Tabel 1. Hasil Analisis Regresi dan Perhitungan Respons Permintaan

\begin{tabular}{lrrrrrr}
\hline Jenis Pangan & \multicolumn{1}{c}{$\mathrm{B}_{0}$} & \multicolumn{1}{c}{$\mathrm{B}_{1}$} & $\mathrm{R}^{2}$ & $\begin{array}{c}\text { Respons } \\
\text { Permintaan }\end{array}$ & $\begin{array}{c}\text { Jumlah } \\
\text { Penduduk/thn }\end{array}$ & $\begin{array}{c}\text { Rata-rata } \\
\text { Konsumsi/thn }\end{array}$ \\
\hline Padi-padian & $-17,931$ & 4,33 & 0,85 & 8,026 & 4,729192 & 2,55167 (T) \\
\hline Daging & $-63818,298$ & 20273,366 & 0,88 & 2,990 & 4,729192 & 32058,33 (ton) \\
\hline Telur & $-114858,58$ & 31610,335 & 0,92 & 4,316 & 4,729192 & 34632,75 (ton) \\
\hline Susu & $-296204,92$ & 67440,419 & 0,81 & 14,029 & 4,729192 & 22733,75 (ton) \\
\hline
\end{tabular}

Nilai koefisien regresi $\beta$ baik untuk pangan padi-padian, daging, telur, maupun susu, bernilai positif dan lebih besar dari 1. Artinya jika jumlah penduduk bertambah, maka permintaan terhadap pangan padi-padian, daging, telur dan susu akan meningkat dengan persentase yang lebih besar dari pertambahan penduduk. Hal ini menuntut penyediaan pangan padipadian, daging, telur dan susu dalam jumlah yang relatif besar dari tahun ke tahun, sehingga perlu diantisipasi baik dari sisi permintaan maupun dari sisi penawaran agar tidak terjadi kekurangan pangan di Sumatera Barat.

Dari sisi penawaran, seperti yang dijelaskan oleh Khairati (2012) di beberapa kabupaten dan kota di Sumatera Barat sudah terjadi ketidak seimbangan produksi pangan dengan pertumbuhan penduduk, dimana pertumbuhan penduduk lebih tinggi dari pertumbuhan produksi pangan, khususnya beras, daging dan telur. Oleh karena itu perlu meningkatkan penyediaan pangan melalui peningkatan produktivitas dan jumlah lahan 
pertanian. Dari sisi permintaan, untuk mengurangi pertumbuhan permintaan, perlu pengendalian pertumbuhan penduduk dengan kebijakan keluarga berencana.

\section{Respons Permintaan Padi-padian}

Hubungan antara permintaan padi-padian penduduk di Sumatera Barat dengan Jumlah penduduk Sumatera Barat, dapat dilihat dengan menggunakan regresi. Dari hasil regresi didapat angka koefisien regresi $(\beta)$ sebesar 4,33 (Tabel1). Angka ini menunjukkan besarnya pertambahan pengeluaran untuk padi-padian (permintaan beras) jika jumlah penduduk bertambah satu juta jiwa.

Setelah mengalikan angka koefisien regresi dengan rasio rata rata jumlah penduduk per tahun dengan rata rata pengeluaran penduduk untuk padipadian per tahun, didapat angka elastisitas atau respons permintaan padipadian terhadap penduduk di Sumatera Barat sebesar 8,026. Angka ini dapat diinterpretasikan bahwa jika penduduk Sumatera Barat bertambah 1\%, maka permintaan penduduknya akan pangan padi-padian bertambah sebesar $8 \%$, artinya pertambahan permintaan pangan penduduk akan padi-padian delapan kali lebih besar dibandingkan dengan kenaikan jumlah penduduk jika jumlah penduduk bertambah.

Angka tersebut memperlihatkan bahwa dengan semakin tingginya jumlah penduduk, pengeluaran penduduk untuk konsumsi padi-padian juga semakin tinggi. Sesuai dengan hasil penelitian Yanel dan Agustien (2016), jumlah penduduk merupakan faktor utama penyebab pertumbuhan permintaan beras, sedangkan kenaikan harga beras walaupun berpengaruh tetapi kecil sekali. Dari angka koefisien determinasi regresi jumlah penduduk dan pengeluaran penduduk untuk padipadian sebesar 0,85 menunjukkan bahwa perubahan variabel jumlah penduduk dapat menjelaskan perubahan pengeluaran penduduk untuk padipadian sebesar $85 \%$, sisanya hanya $15 \%$ dijelaskan oleh variabel lain yang mempengaruhi permintaan pangan padipadian (harga, harga pangan yang berkaitan, pendapatan penduduk, selera penduduk, dan ramalan masa yang akan datang). Hal yang hampir sama juga ditunjukkan oleh hasil penelitian Dewi dan Libria (2016) yang menyatakan bahwa jumlah penduduk berpengaruh signifikan terhadap permintaan pangan beras di Kota Surakarta, disamping harga beras, harga telur dan pendapatan. 


\section{Respons Permintaan Daging}

Dari hasil regresi hubungan antara permintaan daging penduduk Sumatera Barat dengan jumlah penduduk Sumatera Barat didapat angka koefisien regresi sebesar 20273,366 (Tabel 1). Rata-rata jumlah penduduk per tahun sebesar 4,72919 jutajiwa dan rata-rata konsumsi penduduk untuk daging per tahun sebesar 32058,3333 ton; didapat besarnya koefisien elastisitas permintaan daging terhadap penduduk adalah 2,99. Artinya jika jumlah penduduk bertambah 1\%, maka permintaan daging penduduk bertambah sebesar 2,99\%. Dengan kata lain pertambahan permintaan daging tiga kali lebih tinggi dari pertambahan jumlah penduduk.

Dari hubungan antara jumlah penduduk dan konsumsi daging penduduk dapat dilihat bahwa dengan meningkatnya jumlah penduduk setiap tahun, permintaan pangan daging juga meningkat yang diperlihatkan oleh koefisisen regresi sebesar 20273,366. Namun hasil ini berbeda dengan penelitian Haromain di Indonesia (2010) yang menunjukkan bahwa peningkatan jumlah penduduk tidak berpengaruh terhadap permintaan pangan daging. Hal ini bisa saja terjadi, karena di Sumatera Barat daging merupakan makanan penting sehari-hari bagi masyarakatnya, berbeda dengan rata-rata penduduk Indonesia secara keseluruhan. Dijelaskan oleh Haromain (2010), bahwa pertambahan jumlah penduduk yang tidak diimbangi oleh bertambahnya pendapatan tidak serta merta diikuti dengan meningkatnya permintaan daging di Indonesia.

Angka koefisien determinasi sebesar 0,88 menunjukkan model yang dipakai relatif baik, dimana $88 \%$ variabel jumlah penduduk dapat menjelaskan perubahan permintaan daging penduduk, variabel lain yaitu harga daging dan harga pangan terkait, pendapatan penduduk, selera dan ramalan masa yang akan datang hanya bisa menjelaskan perubahan permintaan daging sebesar $12 \%$.

\section{Respons Permintaan Telur}

Hubungan antara permintaan telur dengan jumlah penduduk di Sumatera Barat didapat dari hasil regresi antara konsumsi penduduk untuk pangan telur dengan jumlah penduduk. Besarnya koefisien regresi yang menunjukkan hubungan antara kedua variabel tersebut adalah sebesar 31610,335. Perkalian antara besarnya koefisien regresi dengan rasio rata-rata 
jumlah penduduk 4.729.192 jiwa dan rata-rata konsumsi penduduk untuk telur 34632,750; maka diperoleh elastisitas permintaan telur dengan jumlah penduduk sebesar 4,316. Artinya jika penduduk bertambah $1 \%$ maka permintaan penduduk untuk telur bertambah 4,316\%. Hubungan permintaan telur penduduk dengan jumlah penduduk menunjukkan hubungan positif, dimana dengan bertambahnya jumlah penduduk, permintaan untuk telur juga meningkat.

Hal ini juga ditunjukkan oleh nilai koefisien regresi hubungan antara jumlah telur yang dikonsumsi dengan jumlah penduduk $(\beta)$ bertanda positif sebesar 31610,335. Hal ini sejalan dengan penelitian Fitrini dkk (2006) yang menunjukkan bahwa dengan meningkatnya jumlah penduduk di kota Padang, permintaan terhadap telur juga meningkat. Hasil penelitian Fitrini dkk (2006); juga menunjukkan bahwa respons pertambahan penduduk bersifat elastis terhadap permintaan telur penduduk di kota Padang.

\section{Respons Permintaan Susu}

Besarnya koefisien regresi yang menunjukkan hubungan antara permintaan susu penduduk dengan jumlah penduduk di Sumatera Barat didapat dari hasil regresi antara konsumsi penduduk untuk pangan susu dengan jumlah penduduk. Besarnya koefisien regresi yang menunjukkan hubungan antara kedua variabel tersebut adalah sebesar 67440,419. Perkalian antara besarnya koefisien regresi dengan rasio rata-rata jumlah penduduk 4,729.juta jiwa dan rata-rata konsumsi penduduk untuk susu 22733,750; menghasilkan elastisitas permintaan susu terhadap jumlah penduduk sebesar 14,029. Artinya respons pertambahan permintaan susu jika penduduk bertambah $1 \%$ adalah sebesar $14,03 \%$, atau jika jumlah penduduk bertambah $1 \%$, maka permintaan susu bertambah $14,03 \%$.

Hubungan antara jumlah penduduk dan konsumsi susu penduduk juga menunjukkan angka yang positif, artinya dengan bertambahnya jumlah penduduk, permintaan susu juga bertambah, dengan angka kemiringan garis regresi sebesar 67440,419. Tingginya respons permintaan penduduk untuk susu terhadap pertumbuhan penduduk dibandingkan pangan padi-padian, daging dan telur, dapat disebabkan karena sudah tingginya kesadaran masyarakat terhadap pentingnya konsumsi susu 
untuk kesehatan. Dari hasil penelitian Sartika dan Jum'atri (2011) diduga harga susu dan jumlah anggota rumah tangga berpengaruh terhadap konsumsi susu, tetapi dengan nilai $\mathrm{R}^{2}$ yang diperoleh sangat kecil yaitu 0,080 .

\section{KESIMPULAN}

1. Respons permintaan pangan padipadian terhadap perubahan jumlah penduduk di Sumatera Barat adalah 8 , yang menunjukkan bahwa peningkatan jumlah penduduk sebesar $1 \%$ akan meningkatkan permintaan pangan padi-padian sebesar $8 \%$.

2. Respons permintaan daging terhadap perubahan jumlah penduduk di Sumatera Barat adalah 2,99, yang menunjukkan bahwa peningkatan jumlah penduduk sebesar $1 \%$ akan mengakibatkan peningkatan permintaan daging sebesar $2,99 \%$.

3. Respons permintaan telur terhadap perubahan jumlah penduduk di Sumatera Barat adalah 4,32 yang menunjukkan bahwa peningkatan jumlah penduduk sebesar 1\%, akan mengakibatkan peningkatan permintaan penduduk untuk telur sebesar $4,32 \%$.

4. Respons permintaan susu terhadap perubahan jumlah penduduk adalah
14, yang menunjukkan bahwa peningkatan jumlah penduduk sebesar $1 \%$, akan mengakibatkan peningkatan permintaan penduduk untuk susu sebesar $14 \%$.

\section{REKOMENDASI}

1. Angka respons permintaan untuk pangan (padi-padian, daging, telur dan susu) di Sumatera Barat sangat tinggi diatas 1, yang berarti bahwa permintaan terhadap pangan padipadian, daging, telur dan susu akan bertambah sangat besar dibandingkan pertambahan jumlah penduduk. Hal ini menuntut penyediaan pangan padi-padian, daging, telur dan susu dalam jumlah yang relatif besar dari tahun ke tahun. Oleh sebab itu pemerintah perlu meningkatkan penyediaan pangan melalui peningkatkan produktivitas dan jumlah lahan pertanian.

2. Pemerintah perlu mengantisipasi pertumbuhan permintaan pangan dengan upaya-upaya penurunan tingkat pertumbuhan penduduk melalui pengendalian jumlah penduduk dengan keluarga berencana dan upaya-upaya peningkatan produktivitas produksi 
pangan secara simultan dan berkesinambungan

3. Masyarakat dan pemerintah harus berkomitmen untuk menjalankan kebijakan terhadap program keluarga berencana dan peningkatan produktivitas pangan secara simultan dan berkesinambungan. Untuk itu peran penyuluh sangatlah penting, baik penyuluh pertanian untuk peningkatan produktivitas pertanian, maupun penyuluh keluarga berencana.

4. Untuk meningkatkan produksi dan produktivitas pangan perlu dilakukan pembukaan lahan baru terutama untuk daerah yang potensial, melakukan pengembangan penelitian teknologi produksi, pengendalian dan pengawasan alih fungsi lahan pertanian, serta upaya pengembangan jaringan distribusi pangan yang efisien dan efektif.

\section{DAFTAR PUSTAKA}

BKKBN, 2015. Pembangunan Kependudukan Dalam RPJMD Provinsi Sumatera Barat. Pengintegrasian Isu Kependudukan Dalam Renstra Kabupaten Kota.
Badan Ketahanan Pangan. 2015. Data Statistik Ketahanan Pangan. Kementrian Pertanian, Jakarta.

Dewi dan Libria (2016). Analisis Faktor-Faktor Yang Mempengaruhi Permintaan Beras di Kota Surakarta. Agronomika Vol. 10. No. 02.

Eriandi. H. 2012. Peran Perekonomian Nasional Guna Ketahanan Pangan.http://hermawaneriandi. Com.

Fitrini, Andri dan Yanti. 2006. Analisis Permintaan Telur Ayam Ras di Kota Padang dan Faktor Yang Mempengaruhinya. Jurnal Peternakan Indonesia 11(2) : 112-122.

Haromain, Iman. 2010. Faktor-Faktor Yang Mempengaruhi Permintaan Daging Sapi di Indonesia Pada Tahun 20002009. Skripsi. Program Studi Agribisnis Fakultas Sains dan Teknologi, Universitas Islam Negri, Jakarta.

Khairati, R. 2012. Ketersediaan Pangan di Sumatera Barat, BKKBN Provinsi Sumatera Barat.

Khairati, R. 2014. Perbandingan Pertumbuhan Produksi Pangan dan Pertumbuhan Penduduk pada Wilayah Kabupaten di Provinsi Sumatera Barat.Jurnal KBPVolume 2 No.1.

Mardianto.2014. Analisis Konversi Lahan Sawah di Kota Solok. Tesis Magister Program Studi Ilmu Ekonomi Pertanian. Program Pascasarjana Fakultas 
Pertanian. Universitas Andalas, Padang

Nurbaiti. 2013. Faktor-faktor Yang Mempengaruhi permintaan Telur Ayam di Kota Banda Aceh. Fakultas Ekonomi Unsyiah.

Peraturan Pemerintah No. 38 Tahun 2007. Tentang Pembagian Urusan Pemerintah antara Pemerintah Pusat, Pemerintah Provinsi dan Pemerintah Kabupaten/Kota.

Peraturan Pemerintah Nomor 28 Tahun 2004. Tentang Keamanan, Mutu, dan Gizi Pangan.

Pusat Data dan Sistem Informasi Pertanian. 2012. Statistik Konsumsi Pangan Tahun 2012. Kementerian Pertanian, Jakarta.

Raharja, P dan Mandala Manurung.2004. Pengantar Ilmu Ekonomi (Mikro Ekonomi dan Makro Ekonomi) Penerbit Fakultas Ekonomi, Universitas Indonesia.

Rosyidi. S. 1998. PengantarTeori Ekonomi. Pendekatan Kepada Teori Ekonomi Mikro \& Makro. Edisi Baru. PT. Raja Grafindo Persada, Jakarta.

Riyanto, W, M. Ridwansyah, dan Umiyati, E. 2013. Permintaan Beras di Provinsi Jambi.Jurnal Perspektif Pembiayaan dan Pembangunan Daerah.Vol.1. No. 1.Juli 2013.

Sartika dan Jum'atri Yusri (2011). Konsumsi Susu di Sumatera
Barat. Jurnal Agripita, Vol.1. No.1. April 2011 : 21-23

Sumatera Barat Dalam Angka. 20022013. Kerjasama Badan Perencanaan Pembangunan Daerah dan Badan Pusat StatistikSumatera Barat. Padang.

Sukirno, S. 2002. Pengantar Teori Mikro Ekonomi, Edisi 3. Rajawali Press, Jakarta.

Sumaryanto, Hermanto dan Pasandaran, E. 1996.Dampak Konversi Lahan Sawah Terhadap Pelestarian Swasembada Beras dan Soaial Ekonomi Petani.Dalam Prosiding Seminar Persaingan Dalam Pemanfaatan Sumberdaya Lahan dan Air. Dampaknya Terhadap Keberlanjutan Swasembada Beras. Pusat Penelitian Sosial EkonomiPertanian dan Ford Fondation. Bogor.

Undang-undang Nomor 32 tahun 2004. Tentang Pemerintahaan Daerah

Undang-undang Nomor 23 Tahun 2014. Tentang Pemerintahan Daerah.

Undang-undang Nomor 18 Tahun2012. Tentang Pangan.

Varian, H.R. 1990. Intermediate Microeconomics, A Modern Approach. Second Edition. W.W Norton \& Company. New York.

Wibowo, R. 2000. Penyediaan Pangan dan Permasalahannya dalam Pertanian dan Pangan. Pustaka Sinar Harapan, Jakarta. 
Yanel, Kurnia Agustien. 2016. Analisis

Faktor-faktor Yang Mempengaruhi
Pangan Beras di Provinsi Sumatera Barat. Tesis, Universitas Andalas. 